\title{
ELECTRONIC RAT-CONTROL DEVICES - SOLUTION OR SCAM? RESULTS OF FIELD TRIALS AND A SUMMARY OF THE LITERARY DATA
}

\author{
Georgi Zhelev $^{1 \star}$, Koycho Koev ${ }^{1}$, Viktor Stoyanov², Vladimir Petrov ${ }^{1}$ \\ ${ }^{1}$ Department of Veterinary Microbiology, Infectious and Parasitic Diseases, \\ Faculty of Veterinary Medicine, Trakia University, 6000 Stara Zagora, Bulgaria. \\ ${ }^{2}$ Student, Faculty of Veterinary Medicine, Trakia \\ University, 6000 Stara Zagora, Bulgaria.
}

Abstract

The electronic rat-control devices are humane means of controlling harmful rodents without toxic substances. They are relatively inexpensive and very easy to use and have gained increasing popularity in recent years. Although they have been introduced long ago in the practice of deratization, scientific information about their real effectiveness is scarce and at the same time very controversial. The purpose of this study was to evaluate the repellent efficiency of an electronic device using the combined action of ultrasonic waves, light signals, and electromagnetic field change in practice. Two field trials were carried out on a cattle-breeding farm and a feed warehouse inhabited by brown rats (Rattus norvegicus) and roof rats (Rattus rattus). Repellent efficacy was determined by comparing the indicators evaluating the presence and activity of rodents during the pre-testing period before the inclusion of the device and after its activation during the test period. A lack of repellent effect was found in both field studies. The results obtained are supported by an analysis of the scientific literature confirming the inadequate effectiveness of electronic rat control devices in practical conditions. Emphasis is placed on the deficiencies and the need for regulatory adjustments governing the control and admission of electronic devices to control rats on the market.

Keywords: deratization, ultrasound, electromagnetic, electronic device, rat control.

\footnotetext{
${ }^{1}$ Corresponding author: zhelev_vet@abv.bg
} 


\title{
ELEKTRONSKI UREĐAJI ZA KONTROLU PACOVA - REŠENJE ILI PREVARA? REZULTATI TERENSKIH ISPITIVANJA I PREGLED LITERATURNIH PODATAKA
}

\author{
Georgi Zhelev ${ }^{1 *}$, Koycho Koev ${ }^{1}$, Viktor Stoyanov ${ }^{2}$, Vladimir Petrov ${ }^{1}$ \\ ${ }^{1}$ Departman za veterinarsku mikrobiologiju, infektivne i parazitske bolesti, \\ Fakultet veterinarske medicine, Univerzitet Trakia, 6000 Stara Zagora, Bugarska \\ ${ }^{2}$ Student, Fakultet veterinarske medicine, Univerzitet \\ Trakia, 6000 Stara Zagora, Bugarska
}

\begin{abstract}
Elektronski uređaji za kontrolu pacova predstavljaju humano sredstvo za kontrolu štetnih glodara bez toksičnih supstanci. Ovi uređaji su relativno jeftini, veoma lako se koriste i postaju sve popularniji tokom poslednjih nekoliko godina. Iako su već odavno prisutni u praksi, naučni dokazi o njihovoj efikasnosti su šturi, a istovremeno i vrlo diskutabilni. Cilj ove studije bila je evaluacija efikasnosti repelentne zaštite elektronskog uređaja koji primenjuje kombinovano dejstvo ultrazvučnih talasa, svetlosnih signala i promene elektromagnetnog polja u praksi. Sprovedena su dva terenska ispitivanja - jedno na farmi goveda, a jedno u skladištu stočne hrane koje su naseljavali sivi pacovi (Rattus norvegicus) i crni pacovi (Rattus rattus). Efikasnost repelentne zaštite odredjivana je na osnovu poređenja indikatora za prisustvo i aktivnost glodara tokom perioda pre istraživanja i uvodjenja uredjaja i nakon aktivacije uređaja tokom eksperimentalnog perioda. Odsustvo repelentnog efekta ustanovljeno je u obe terenske studije. Dobijene rezultate potkrepljuje i analiza naučne literature koja potvrđuje neadekvatnu efikasnost elektronskih uređaja za kontrolu pacova u praktičnim uslovima. Naglasak je stavljen na manjkavosti i potrebu za zakonskim usklađivanjem u oblasti kontrole i puštanja u promet elektronskih uređaja za kontrolu pacova.
\end{abstract}

Ključne reči: deratizacija, ultrazvuk, elektromagnetni, elektronski uređaj, kontrola pacova. 


\section{INTRODUCTION}

The electronic rat-control devices are an alternative to the chemical method of controlling harmful rodents and have gained increasing popularity in recent years. It is believed that these are humane means of reducing the number of rodents on a given territory as they create an environment with unfavourable conditions for their development but without causing a strong pain response, agony or death. Due to the absence of toxic substances they are considered to be environmentally safe. The devices are relatively inexpensive and very easy to use (Bomford and O'Brien, 1990). Electronic rat-control devices use different principles to repel rodents - some emit ultrasonic waves that negatively affect rodents, while others modify the electromagnetic field around electric conductors or emit sudden and strong light signals. Despite a wide variety of different commercially available models, as well as extensive media advertising, many users report unsatisfactory performance in practice. The information on their effectiveness in the scientific literature is scarce and at the same time there is a serious contradiction between the results of tests carried out in laboratory and field conditions (Maclean, 1970; Shumake et al., 1982; Shumake et al., 1984; Shumake, 1997). This motivated us to conduct our own research to assess the suitability of these agents for controlling synanthropic rodents in real-world practice.

\section{MATERIALS AND METHODS}

The repellent efficacy in field conditions of an electronic device (Pest X Repel, model PR-500.3, Microsys Co Ltd., Bulgaria) with a combined action was tested. The device emits ultrasonic signals at a frequency of $15-36 \mathrm{kHz}$ and changes the electromagnetic field in the objects. At the same time, with the built-in flash lamp, it also emits sudden, powerful light signals at a frequency of 75 units per minute. The device is programmed to permanently change the shape and frequency of the transmitted pulses in order to avoid rodents accustoming to them. According to the manufacturer, one appliance is sufficient to repel rodents on an area of $200 \mathrm{~m}^{2}$, with the initial repellent effect occurring within 1-2 weeks, and the maximum effect is achieved after the third week. During this period, rodents should leave their hiding places and the protected site (Annonimous).

The studies were conducted in two areas inhabited by rodents:

Site №1 - a cattle-breed farm infested by brown rats (Rattus norvegicus) with high density $\left(50-100\right.$ specimens $\left./ 100 \mathrm{~m}^{2}\right)$. The device was placed near an 
electrical distribution board in a barn of about $180 \mathrm{~m}^{2}$.

Site №2 - a feed warehouse infested by roof rats (Rattus rattus) with medium density (10 - 50 specimens $/ 100 \mathrm{~m}^{2}$ ). The device was placed near an electrical distribution board in an area of $50 \mathrm{~m}^{2}$.

The repellent efficiency of the electronic device in the objects was determined by comparing indicators that evaluated the activity and the number of rodents during the pre-test period before the inclusion of the device and after its activation during the test period. The following was determined: the number of food sources visited, the average daily consumption of non-toxic food bait, the number of dusty track plates visited and the intensity of the traces left, as well as the number of active holes (only in the site №1, infested by brown rats with digging activities). These indicators were determined every 5 days during the ten days pre-test period and during the test period, which was 35 days in the cattle-breeding farm and 60 days in the feed warehouse.

The statistical data analysis was processed using GraphPad software. Comparison of results between the groups was done using unpaired t-test. Differences were defined as statistically significant in values of $\mathrm{P}<0.05$.

\section{RESULTS}

The results of the field trials are presented in table 1. In both sites, no statistically significant decreases in rodent density and activity were detected after activation of the electronic device.

Table 1. Dynamics in rodent density and activity during the pre-test and test period. 


\begin{tabular}{|c|c|c|c|c|c|c|c|c|c|c|c|}
\hline \multirow{13}{*}{ 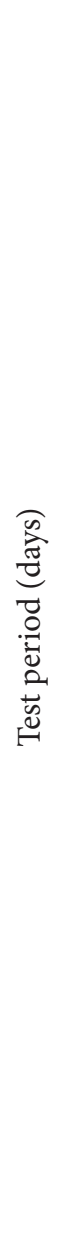 } & 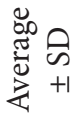 & $\hat{a}$ & 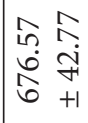 & 으 & $\begin{array}{l}+ \\
+\end{array}$ & $\hat{\bumpeq}$ & రె & $\stackrel{\frac{m}{a}}{\stackrel{2}{a}}$ & 으 & + & 离 \\
\hline & 营 & ' & ' & 1 & 1 & ' & in & $\stackrel{\infty}{=}$ & 으 & + & U \\
\hline & 点 & 1 & ' & ' & 1 & ' & 으 & $\stackrel{n}{\simeq}$ & 으 & + & 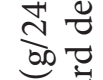 \\
\hline & 竎 & ' & ' & ' & ' & ' & $\infty$ & I & 으 & + & : \\
\hline & 章 & ' & ' & 1 & ' & ' & $\wedge$ & $\stackrel{\stackrel{2}{\simeq}}{\simeq}$ & 으 & + & \\
\hline & 홍 & ' & ' & ' & ' & ' & $\Lambda$ & 슨 & 으 & + & \\
\hline & $\stackrel{5}{10}$ & $\infty$ & 웃 & 으 & $\begin{array}{l}+ \\
+\end{array}$ & $\stackrel{\infty}{\sim}$ & $\infty$ & 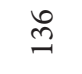 & 으 & + & \\
\hline & ప્ & 으 & ำ & $\stackrel{ }{\circ}$ & $\stackrel{+}{+}$ & 10 & in & $\stackrel{\infty}{\underset{+}{+}}$ & 으 & $\stackrel{+}{+}$ & \\
\hline & $\stackrel{\mathscr{L}}{\sim}$ & 으 & 웅 & 으 & $\stackrel{+}{+}$ & $\stackrel{10}{-1}$ & 으 & 으 & 으 & $\stackrel{+}{+}$ & 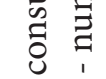 \\
\hline & Ð્ટ & 으 & $\stackrel{\sim}{\mathrm{\sigma}}$ & 으 & $\begin{array}{l}+ \\
+\end{array}$ & $\ddot{\sim}$ & in & $\stackrel{\infty}{\infty}$ & 으 & $\stackrel{+}{+}$ & 矛 \\
\hline & 莒 & 으 & 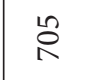 & 으 & $\stackrel{+}{+}$ & $\stackrel{0}{-1}$ & $\infty$ & 6 & 으 & $\stackrel{+}{+}$ & \\
\hline & పే & $\stackrel{ㅇ}{-}$ & $\overrightarrow{\widetilde{\sigma}}$ & 으 & $\stackrel{+}{+}$ & 고 & in & 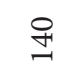 & 으 & $\begin{array}{l}+ \\
+ \\
+\end{array}$ & 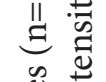 \\
\hline & in & 오 & \& & 으 & $\stackrel{+}{+}$ & $\triangleq$ & in & $\begin{array}{l}10 \\
\stackrel{1}{n}\end{array}$ & 으 & $\stackrel{+}{+}$ & \\
\hline 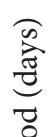 & 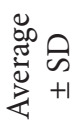 & 으 & $\begin{array}{ll}1 & n \\
1 & 9 \\
0 & 9 \\
0 & +1\end{array}$ & 으 & $\begin{array}{l}+ \\
+ \\
+\end{array}$ & 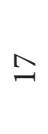 & $\wedge$ & 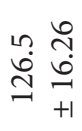 & 으 & $\stackrel{+}{+}$ & 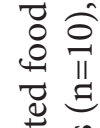 \\
\hline 岕 & 흠 & 으 & 오 & 으 & $\begin{array}{l}+ \\
+\end{array}$ & $\stackrel{2}{ }$ & $\infty$ & $\stackrel{\infty}{\sim}$ & 으 & $\stackrel{+}{+}$ & 点 \\
\hline 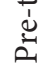 & in & 으 & 유 & 으 & $\begin{array}{l}+ \\
+\end{array}$ & $\stackrel{10}{n}$ & 6 & $\stackrel{10}{=}$ & 으 & + & 胥 \\
\hline & & \& & $\vec{n}$ & $\widetilde{u}$ & $\overline{0}$ & 디 & $\underset{z}{2}$ & $\stackrel{\sim}{\oplus}$ & $\mathcal{J}$ & $\tilde{\mathrm{A}}$ & $\dot{్}$ \\
\hline & & & سurf 8 & !рәа & $\mathrm{MO}^{\prime}$ & & & почәI & $\mathrm{Mp}$ & & 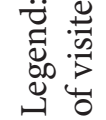 \\
\hline
\end{tabular}




\section{DISCUSSION}

The scientific literature data on the effectiveness of electronic repellent devices revealed a significant contradiction between the results of tests carried out in controlled laboratory conditions with small groups of synanthropic rodents and those performed in real practice in field studies. For example, in the laboratory tests performed by Maclean (1970) to evaluate the repellent properties of an ultrasound device, satisfactory efficacy was found in the repulsion of rats and mice. However, he found higher repellent efficiency in cases where he gave rodents free access to alternative sources of food and water in ultrasonic free spots (Maclean, 1970). Similar results in laboratory conditions were obtained from Shumake et al. (1982), who studied the impact of three ultrasound devices $(20,20-30$ and $40 \mathrm{kHz})$ on the behaviour and intake of food in Philippine black rats (Rattus rattus mindanensis). They found that when the food was plentiful, the rats significantly reduced the intake of food in ultrasound chambers, preferring to feed in the chambers without ultrasonic waves. However, when the food was limited, insufficient to meet the physiological needs of rats, only $20-30$ and $40 \mathrm{kHz}$ chambers showed a decrease in dietary intake compared to the control chamber. The authors note that the achieved repellent effect was partial - despite lower food intake, the cameras were still visited by rodents, which in practice does not exclude epidemiological risks and in some cases proved to be insufficiently effective, such as in the food industry (Shumake et al., 1982).

Unlike comparatively positive results in laboratory tests, the performance data of electronic repellent devices in real-world practice conditions are definitely negative. Already in 1962, Marsh et al. reported a lack of efficiency of a $15 \mathrm{kHz}$ ultrasonic generator in a grain storage facility (Marsh et al., 1962). Similar are the results of Sprock et al. (1967), who studied the efficiency of an electronic generator emitting sound and ultrasonic waves in the range of 1.8 $48 \mathrm{kHz}$ in domestic mice and rats.

Lavoie and Glahn (1977) conducted field trials in brown-rat sites with two types of ultrasound devices, one with a frequency variation, and the other with a constant frequency of $20 \mathrm{kHz}$. For both sets, manufacturers claimed to have high efficiency in rodent repulsion. After 3 weeks, no statistically significant reduction in rodent activity and food consumption was achieved in the first type of device. In the second type of device, the initial reduction in rodent activity was followed by recovery to baseline levels after the first week, indicating rapid adaptation of rodents. Howard and March (1985) also found that ultrasound devices are not enough effective in practical conditions. 
The large-scale tests on the effectiveness of 6 ultrasound devices available from the United States, conducted by Shumake (1997), found that 5 of them did not exhibit even a minimal repellent effect, and one of the devices had a partial temporary effect - just 3 days after the start of the tests, restoration of the initial parameters of the number of rodents started. Based on the obtained results, these devices have been identified as practically ineffective. The same author note that 25 years after the ultrasound device was started, there is still no conclusive scientific evidence demonstrating their effectiveness in the repulsion of synantropic rodents (Shumake et al., 1984).

Scientific data on the other type of electronic devices (electromagnetic) are similar. Thus, in a US study on the effectiveness of an electromagnetic repellent device in a feed stock house infested by house mice, it was found that 2 weeks after activation, traces of rodents were observed in $50 \%$ of the tracking sites. After 3 weeks, the number of sites has increased to $75 \%$, including those in close proximity to the device, which is an indication of an increase in rodent activity and insufficient efficiency of the electromagnetic device (Fitzwater, 1978). Rooney and McKeen (1977) also did not detect a statistically significant decrease in the number of domestic mice inhabiting a poultry farm in California (USA) after an electromagnetic device was inserted. The effectiveness of the same device was previously investigated by Kruger in 1975, who even found an increase in the number of rodents in a poultry farm during the testing of the device (Fitzwater, 1978). Similar results in tests with another electromagnetic device were obtained by Steve Palmateer (1977, EPA Animal Biology Laboratory, Beltsville, Maryland, USA), who found very small, statistically insignificant differences in food consumption, breeding and activity of brown rats from the control and experimental group (Fitzwater, 1978).

In our field studies with a combined electronic device emitting ultrasonic waves, strong light signals and electromagnetic field changes, similar results were obtained to the above results. No statistically significant differences in rodent density and activity were found in both the cattle-breed farm, infested by brown rats and the feed warehouse, infested by roof rats. On the basis of the results obtained, it can be concluded that the electronic device has an unsatisfactory repellent efficiency in the practice conditions of objects inhabited by these two species of rodents.

In support of our results and conclusions, Bomford and O'Brien (1990) studies aim to analyze and summarize the published research on the effectiveness of ultrasonic devices in the control of harmful animal species. Summing up dozens of different scientific reports, they found that ultrasound devices were either ineffective in practice, or their effect was partial and temporary, 
and concluded that they were unsuitable for practice. Shumake (1997) makes a similar summary of electromagnetic efficiency, based on a large-scale study by the US Environmental Protection Agency (Annonimous, 1980), which conclusively demonstrated the absence of any negative impact on the devices in the feeding, water intake, reproduction and displacement of brown rats. Consequently, based on the results obtained, the EPA fined the manufacturers of these devices and filed lawsuits (Shumake, 1997).

The low efficiency of electronic devices in practice causes the European and Mediterranean plant protection organization (EPPO, France) to declare that the use of these devices is not a good GPP in rodent control (OEPP/EPPO, 1998).

Why do these devices continue to advertise and market? The answer to this question may lie in the fact that in 1982 only in the United States the sales of ultrasonic repellent devices amounted to 17 million dollars and in the next decades they have increased many times. It is clear that it is a highly profitable business, suggesting that the problem can only be solved if much stricter and radical legislative measures are introduced (Bomford and O 'Brien, 1990; Mix, 1984). In this regard, the Federal Trade Commission (FTC, USA) establishes that many manufacturers produce repellent devices that claim to be highly effective in repelling rodents, but these claims are often not supported by research results. That's why, in 2001, the FTC warned more than 60 companies in the USA that produced, advertised and sold electronic pest-control devices whose efficiency was not supported by any research (Federal Trade Commission, 2001).

At the same time, it has to be noted that many users report the success of rodent evasion and high efficiency of electronic devices. These assessments are in most cases subjective and could not serve as a basis for general conclusions, but should not be overlooked either. Unfortunately, at present, there is no list of producers and trademarks for which there is scientific evidence or reliable reviews of the practice for their high efficiency as well as those that are a typical counterfeit. Therefore, ordinary users and deratization professionals are very often involved in misleading misconduct by mass media advertising (Federal Trade Commission, 2003).

\section{LITERATURE}

1. Annonimous: Manufacturer's instruction. Available at http://pest-x-repel. com/bg/products/PR-500.3/ (26 March 2018, date last accessed).

2. Annonimous: Environmental Protection Agency: Investigation of efficacy and enforcement activities relating to electromagnetic pest control devices. EPA 340102-80-001. Pesticides and Toxic Substances, U.S. EPA 
Enforcement Division, Washington, DC, 216, 1980.

3. Bomford M., O'Brien P.: Sonic deterrents in animal damage control: A revive of device test and effectiveness. Wildlife Society Bulletin, 18, 411-422, 1990.

4. Federal Trade Commission (FTC): Warns Manufacturers and Retailers of Ultrasonic Pest-control Devices. Marketer of Pest Control Devices Required to Provide Support for Claims, 2003. http://www.ftc.gov/news-events/ press-releases/2003/07/marketer-pest-control-devices-required-providesupport-claims (26 March 2018, date last accessed).

5. Federal Trade Commission: FTC Warns Manufacturers and Retailers of Ultrasonic Pest-control Devices, 2001. Available at: https://www.ftc.gov/ news-events/press-releases/2001/05/ftc-warns-manufacturers-and-retailers-ultrasonic-pest-control (26 March 2018, date last accessed).

6. Fitzwater W.D.: Electromagnetic repellents - fact or fiction? Proceeding Vertebrate Pest Conference, 8, 87-92, 1978.

7. Howard W.E., March R.E.: Ultrasonics and electromagnetic control of rodents. Acta Zoologica Fennica, 173, 187-189, 1985.

8. Lavoie G.K., Glahn J.F.: Ultrasound as a deterrent to Rattus norvegicus. Journal of stored products research, 13, 1, 23-28, 1977.

9. Maclean K.: The effects of ultrasound on the behaviour of commensal rodents with a discussion of its potential it management and control programs. A thesis submitted in partial fulfilment of the requirements for the degree of Master of Science in department of biological sciences. Simon Fraser University, 136, 1970.

10. Marsh B.T., Jackson W.B., Beck J.R.: Use of ultrasonics in elevator rat control. Grain Age, 3, 11, 27-31, 1962.

11. Mix J.: Researches debunk controlling insects with ultrasound. Pest control, 52, 2, 26-28, 1984.

12. OEPP/EPPO: Guidelines on good plant protection practice: PP 2/5(1) "Rodent control for crop protection and on farms". European and Mediterranean Plant Protection Organization, Paris, 1998.

13. Rooney W.F., McKeeny W.D.: A study of rodent repellers for house mouse control. Progress in Poultry (UC-Coop.Ext.), 10, 6, 1977.

14. Shumake S.A., LaVoie G.K., Crane K.: Efficacy test protocols for evaluation of ultrasonic rodent repellent devices. Proceeding Vertebrate Pest Conference, 11, 84-88, 1984.

15. Shumake S.A., Kolz A.L., Crane K.A., Johnson R.E.: Variables affecting ultrasound repellency in Philippine rats. Journal of Wildlife Management, 46, $1,148-155,1982$. 
16. Shumake S.A.: Electronic rodent repellent devices: a review of efficacy test protocols and regulatory actions. In Mason J.R., editor. Repellents in Wildlife Management. USDA, National Wildlife Research Center, Fort Collins, CO, 1997, 253-270.

17. Sprock C.M., Howard W.E., Jacob F.C.: Sound as a deterrent to rats and mice. Journal of Wildlife Management, 31, 4, 729-741, 1967.

Primljeno: 28.03.2018.

Odobreno: 07.07.2018. 